Nig. J. Pure \& Appl. Sci. Vol. 33 (Issue 1, 2020)
eISSN 2756-4045
Life Sciences, Univ. of Ilorin, Nigeria
www.njpas.com.ng

doi: http://dx.doi.org/10.48198/NJPAS/20.A17

\title{
PHYTOCHEMICAL SCREENING AND ANTIMICROBIAL EFFECT OF SEEDS OF Monodora myristica ON SELECTED MICROORGANISMS
}

\author{
Page | $3674 \quad{ }^{1 *}$ F.A. Jimoh, ${ }^{1}$ A.T. Ajao, ${ }^{2}$ R.F. Zakariyah, ${ }^{2}$ M.B. Odebisi-Omokanye, ${ }^{1}$ H. O. Abdulrahman \\ ${ }^{1}$ Department Of Biosciences and Biotechnology, Microbiology Unit, College of Pure and Applied Sciences, Kwara \\ State University, Malete \\ ${ }^{2}$ Department of Microbiology, Faculty of Life Sciences, University of Ilorin
}

\begin{abstract}
The increase in the prevalence of effects of many synthetic antimicrobial agents and incidence of multiple drug resistant microorganisms has spurred scientists on the research for plant-based antimicrobial of therapeutic potentials. The Monodora myristica has been used in Nigeria traditionally as condiments and has been harnessed as a therapeutic agent in the treatment of skin infection and dysentery. Aqueous, $n$-hexane and ethanolic extracts of the seeds was screened for antimicrobial activity against pathogenic microorganisms implicated in causing vagina infections. This finding showed that the efficacy of the extracts was concentration dependent. Aqueous, ethanolic and $\mathrm{N}$-hexane extract showed varying degree of inhibition with different magnitude against the test isolates. Ethanolic extract showed highest activities against Candida albican, followed by Staphylococcus aureus and Klebsiella pneumoniae with $21.5 \mathrm{~mm}, 19.5 \mathrm{~mm}$ each respectively. The same patterns of of inhibition was also observed in N-hexane extract. The antimicrobial effect of the two extracts were statistically not significant. The extracts had minimum concentration that ranged between $150 \mathrm{mg} / \mathrm{ml}$ and $200 \mathrm{mg} / \mathrm{ml}$. The ethanolic extract showed more inhibitory effects compare to the aqueous and n- hexane extracts. The ethanolic extract found to contain highest quantity of phytochemicals while aqueous extract has lowest amount of the phytochemicals. It is therefore can be affirmed that Monodora myristica seed extracts could be exploited as therapeutic agents to drug resistant microorganisms.
\end{abstract}

Keywords: Monodora myristica, Therapeutic agents, Drug resistant microorganisms

\section{Introduction}

From time immemorial, plants have been utilized worldwide for the treatment of infectious diseases. Nearly $80 \%$ of the World's populace relies on plant-based medicine for the care of their health (Singh and Bindhu, 2019). The plant parts or its products meet societal health need stems from the fact that indiscriminate use of commercial antimicrobial drugs commonly utilized in the treatment of infectious diseases has led to the development of multiple drug resistance (Osuagwu and Onwuegbuchulam, 2015), the use of plants is safe and cost effective in traditional as well as in modern medicine (Treasure et al., 2020). Most of these native plants possess bioactive compounds that exhibit physiological activities microorganisms and are also used as precursors for the production of useful drugs. Thus, the importance of these plant products in medicine is as a result of the

\section{Corresponding Author: F.A. Jimoh}

Biosciences and Biotechnology, Microbiology Unit, College of Pure and Applied Sciences, Kwara State University, Malete. Phone: +234-8062578129: Email: Jimohafausat08@gmail.com 
presence of bioactive compounds such as phenolics, alkaloids, flavonoids, tannins, resins, steroids, and other secondary metabolites which they contain and are capable of producing definite physiological action in the body (Bishnu et al.,

Page | 3675 2009). Phytochemicals carry out essential medicinal roles in the body. There is urgent need for discovery of new antimicrobial compounds with diverse chemical structures and novel mechanisms of action for new and re-emerging infectious diseases (Rojas et al., 2003; Olusimbo et al., 2011).

Hence, this study was aimed at assessing the antimicrobial effects of Monodora myristica seeds on selected human pathogens implicated in causing several infections.

\section{Materials and Methods}

\section{Collection and Identification of Plant Material}

Fresh seeds of Monodora myristica were collected from Oja-Tuntun market Ilorin. The seeds were authenticated as UILH/001/1255 at the Department of Plant Biology, University of Ilorin Kwara State.

\section{Extraction of Monodora myristica Seeds}

Fifty grams of Monodora myristica powder was dissolved in $250 \mathrm{ml}$ sterile distilled water and mixed thoroughly before placing on a mechanical shaker for agitation for 72 hours at $200 \mathrm{rpm}$. The mixture was filtered using Whatman No. 1 filter paper into beakers, to obtain the filtrates; while 50 grams of the blended seed in $250 \mathrm{ml}$ of $70 \%$ ethanol and nhexane in separate flasks, and was extracted using soxlet extractor. The extracts were concentrated using the rotary evaporator (Cole Parmer IKA RV 10 digital) at $50^{\circ} \mathrm{C}$. The concentrates were lyophilized using a freeze-drier (model; U. therm international (H.K) limited FD-12-MR) at $-4^{\circ} \mathrm{C}$ for few days and stored at $4^{\circ} \mathrm{C}$ until needed (Osuagwu and Eme, 2013).

\section{Sterility Test of the Plant Extracts}

This was done by weighing 0.2 grams/ $0.2 \mathrm{ml}$ of each extracts and dissolved $9.8 \mathrm{ml}$ of sterile distilled water was added. Each of the aqueous, ethanol and n-hexane extract's sterility was confirmed by inoculating a drop of each of the extracts on sterile Mueller Hinton agar plates each and incubated at 37 ${ }^{0} \mathrm{C}$ for 24 hours.

\section{Collection and Maintenance of Microbial Isolates}

The microbial isolate used for this study were obtained from the Department of Microbiology, University of Ilorin. These include Staphylococcus aureus ATCC 6538, Streptococcus spp, Enterococcus faecalis ATCC 10231, Klebsiella pnuemoniae, Escherichia coli ST2747, Escherichia coli ATCC 35218 and Candida albicans ATCC 334. The isolates were stock on nutrient agar and potato dextrose agar slant for bacteria and fungi respectively, and kept at $4^{0} \mathrm{C}$. All the microbial isolates were sub-cultured for purification prior to biochemical identification.

\section{Antimicrobial Susceptibility Testing}

Agar diffusion method was adopted for this assay. The antimicrobial activity of the extracts against the test organisms was determined as described by Zakariyah et al. (2017) with slight modifications. A loopful of the standardized bacterial cell suspension $\left(10^{8} \mathrm{cfu} / \mathrm{ml}\right)$ was streaked evenly on each solidified Mueller Hinton agar plate. The seed extracts were reconstituted in 3\% Di-methyl Sulfoxide (DMSO) to obtain the working concentrations of 50, 100, 150 , and $200 \mathrm{mg} / \mathrm{ml}$ (Performance, 2006). $200 \mu \mathrm{l}$ of each extract at different concentrations was inoculated aseptically into five wells $(6 \mathrm{~mm}$ in diameter) earlier bored with sterile cork borer in each plate. The negative control was $200 \mu 1$ of $3 \%$ DMSO; the plates were allowed to stand for 30 minutes for pre-diffusion of the extracts. The plates were incubated upright at $37^{\circ} \mathrm{C}$ for 24 hours for bacteria and $25^{\circ} \mathrm{C}$ for 48 hours for Candida 
albicans. The mean diameter of zones of inhibition was recorded in millimeters $(\mathrm{mm})$.

\section{Standard Antibiotic Testing}

The antibiotic used were Gentamycin $40 \mathrm{mg} / \mathrm{ml}$ Page | 3676 against bacteria, and $25 \mu \mathrm{g}$ of fluconazole against fungi, $200 \mu 1$ of each antibiotics at different concentrations was inoculated into four wells (6 $\mathrm{mm}$ diameter) bored with a sterile cork borer in each plate. $200 \mu 1$ of sterile distilled water was used as a negative control; the plates were allowed to stand for 30 minutes. The plates in duplicates were incubated at $37^{\circ} \mathrm{C}$ and $25^{\circ} \mathrm{C}$ for 24 hours and 48 hours for bacteria and fungi respectively. The mean diameter of zones of inhibition was recorded in millimeters (mm) (Performance, 2006).

\section{Antibiotic Disc Testing}

The antibiotic disc were ciprofloxacin $5 \mu \mathrm{g}$, nitrofurantoin $300 \mu \mathrm{g}$ against bacteria, and $25 \mu \mathrm{g}$ of fluconazole against fungi, The plates in duplicates were incubated at $37^{\circ} \mathrm{C}$ and $25^{\circ} \mathrm{C}$ for 24 hours and 48 hours for bacteria and fungi respectively. The mean diameter of zones of inhibition was recorded in millimeters (mm) (Bamidele et al., 2013).

\section{Determination of the Minimum Inhibitory Concentration (MIC) and Minimum Cidal Concentration (MCC)}

The minimum inhibitory concentrations (MIC) of the extracts were determined by dilution to various concentrations according to the (Nweze and Onyisi, 2010). Standardized inocula of each organism to be tested was added to series of sterile tubes of nutrient broth containing two fold dilution of the extract and incubated at $37^{\circ} \mathrm{C}$ for 24 hours. The MIC was read as the least concentration that inhibited the growth of the test organisms. The minimum bactericidal concentration (MBC) was determined by subculturing the test dilution onto fresh drug-free solid medium and incubating further for 18 to 24 hours. The highest dilution that yielded no single cell colony on the solid medium was taken as the minimum bactericidal concentration.
The seed extracts that demonstrated significant antimicrobial activity were subjected to MIC and MCC assay, using the agar dilution method. The concentration of extracts that produced the least zone of inhibition in the antimicrobial susceptibility test was further diluted for up to two new concentrations. Standardized inocula of each organism to be tested were inoculated on sterile MHA plates. Wells were made using a $4 \mathrm{~mm}$ sterile cork borer on the MHA plates into which the different concentrations of extracts were added aseptically. The plates were incubated and the MIC was read as the least concentration that inhibited the growth of the test organisms (Ukaegbu-Obi et al., 2015; Zakariyah et al., 2017).

Minimum cidal concentration was determined using tubes containing $0.2 \mathrm{ml}$ of different concentrations of the extracts, $9.7 \mathrm{ml}$ of Mueller Hinton Broth and $0.1 \mathrm{ml}$ of standardized inocula of each test organisms. The mixtures were incubated for 18-24 hours. After incubation, $0.1 \mathrm{ml}$ of the broth was inoculated on MHA plates and incubated for 18-24 hours. The highest dilution that yielded no single cell colony on the solid medium was taken as the minimum bactericidal concentration.

\section{Phytochemical Screening of Seed Extracts Qualitative Phytochemical Screening}

The aqueous, ethanolic and n-hexane extracts Monodora myristica seeds were tested for the presence of phytochemicals such as, alkaloids, tannins, phenolics, glycosides, terpenoids, saponins, flavonoids, steroids and phlobatannins using the standard procedures (Ogukwe et al., 2004; Kar, 2007)

\section{Statistical Analysis}

All the results obtained were analyzed using simple statistics of one-way ANOVA (SPSS 20). The data were expressed as mean $\pm \mathrm{SD}$, difference between the means was considered significant at $95 \%$ Confidence Interval 


\section{Results}

Table 1 depicts that the aqueous extract of Monodora myristica seeds were insignificant at concentrations of 50,100 , and $150 \mathrm{mg} / \mathrm{ml}$ except Page | $3677200 \mathrm{mg} / \mathrm{ml}$, where it was mildly significant on $S$. aureus, Streptococcus spp, E. faecalis, Klebsiella pnuemoniae, and Candida albicans.

Table 2 shows that the ethanol extracts of Monodora myristica seeds were highly significant on all the organisms at highest concentration of 200 $\mathrm{mg} / \mathrm{ml}$, except for Escherichia coli ST2747, which was slightly significant. As the concentrations of the extract decreases, the significances of the zones of inhibition decreases.

Table 3 portrays the n-hexane extract of Monodora myristica seeds were also significant but not as high as the ethanolic extract.

Table 4 compares the antimicrobial activity of the extracts against the standard antibiotics which was more effective than the plant extracts.
Table 5 shows that the aqueous extract possessed minimum inhibitory concentration against most of the test organisms at $200 \mathrm{mg} / \mathrm{ml}$ while ethanolic and n-hexane extracts showed minimum inhibitory concentration against most of the test organisms at $150 \mathrm{mg} / \mathrm{ml}$.

Qualitative analyses of phytochemicals in aqueous, ethanolic and n-hexane extracts of Monodora myristica seeds showed the presence of alkaloids, phenolics, steroids and tannins in all extracts while terpenoids and flavonoids were absent in all but glycosides was present in only ethanolic extracts (Table 6).

Figure 1 shows that the ethanolic extract has the most significant level of phytochemical components amongst the three solvents used for the extraction of Monodora myristica seeds except in steroids with high concentration in n-hexane while the aqueous extracts had the lowest concentration in all.

Table 1: Effect of Aqueous Extract of Monodora myristica Seeds on the Test Organisms Using Agar-well Diffusion Method

\section{Concentrations / Zone of Inhibition (mm)}

\begin{tabular}{|c|c|c|c|c|}
\hline Organisms & $200 \mathrm{mg} / \mathrm{ml}$ & $150 \mathrm{mg} / \mathrm{ml}$ & $100 \mathrm{mg} / \mathrm{ml}$ & $50 \mathrm{mg} / \mathrm{ml}$ \\
\hline $\begin{array}{c}\text { Staphylococcus aureus } \\
\text { ATCC } 6538\end{array}$ & $13 \cdot 5 \pm 0 \cdot 50^{\mathrm{a}}$ & $11 \cdot 0 \pm 1 \cdot 00^{\mathrm{b}}$ & $9 \cdot 5 \pm 0 \cdot 5^{\mathrm{bc}}$ & $6 \cdot 0 \pm 1 \cdot 0^{c}$ \\
\hline Streptococcus spp & $12 \cdot 5 \pm 0 \cdot 50^{\mathrm{a}}$ & $10 \cdot 0 \pm 0 \cdot 0^{\mathrm{b}}$ & $8 \cdot 5 \pm 0 \cdot 50^{c}$ & $6 \cdot 0 \pm 0 \cdot 00^{\mathrm{d}}$ \\
\hline $\begin{array}{c}\text { Enterococcus faecalis } \\
\text { ATCC } 10231\end{array}$ & $12 \cdot 5 \pm 0 \cdot 45^{\mathrm{a}}$ & $11 \cdot 5 \pm 0 \cdot 45^{b}$ & $8 \cdot 5 \pm 0 \cdot 50^{c}$ & $6 \cdot 5 \pm 0 \cdot 45^{\mathrm{d}}$ \\
\hline Klebsiella pneumoniae & $13 \cdot 5 \pm 0 \cdot 50^{\mathrm{a}}$ & $11 \cdot 0 \pm 0 \cdot 00^{\mathrm{b}}$ & $10 \cdot 5 \pm 0 \cdot 50^{\mathrm{bc}}$ & $10 \cdot 5 \pm 0 \cdot 50^{\mathrm{c}}$ \\
\hline $\begin{array}{l}\text { Escherichia coli ATCC } \\
35218\end{array}$ & $9 \cdot 0 \pm 0 \cdot 00^{\mathrm{a}}$ & $8 \cdot 0 \pm 0 \cdot 00^{\mathrm{a}}$ & $6 \cdot 0 \pm 0 \cdot 00^{b}$ & $6 \cdot 0 \pm 0 \cdot 00^{\mathrm{b}}$ \\
\hline $\begin{array}{c}\text { Escherichia coli ST2747 } \\
\text { (MDRs) }\end{array}$ & $6.0 \pm 0 \cdot 00^{\mathrm{a}}$ & $6 \cdot 0 \pm 0 \cdot 00^{\mathrm{a}}$ & $6 \cdot 0 \pm 0 \cdot 00^{c}$ & $6 \cdot 0 \pm 0 \cdot 00^{\mathrm{a}}$ \\
\hline $\begin{array}{l}\text { Candida albicans ATCC } \\
334\end{array}$ & $12 \cdot 5 \pm 0 \cdot 50^{\mathrm{a}}$ & $12 \cdot 0 \pm 0 \cdot 50^{\mathrm{a}}$ & $11 \cdot 5 \pm 0 \cdot 50^{\mathrm{b}}$ & $9 \cdot 5 \pm 0 \cdot 50^{c}$ \\
\hline
\end{tabular}


Table 2: Effect of Ethanolic Extract of Monodora myristica Seeds Extract on the Test Organisms Using Agar-well Diffusion Method

\begin{tabular}{|c|c|c|c|c|}
\hline \multirow[t]{2}{*}{ Organisms } & \multicolumn{4}{|c|}{ Concentrations / Zone of Inhibition (mm) } \\
\hline & $200 \mathrm{mg} / \mathrm{ml}$ & $150 \mathrm{mg} / \mathrm{ml}$ & $100 \mathrm{mg} / \mathrm{ml}$ & $50 \mathrm{mg} / \mathrm{ml}$ \\
\hline $\begin{array}{c}\text { Staphylococcus aureus } \\
\text { ATCC } 6538\end{array}$ & $19 \cdot 0 \pm 0 \cdot 50^{\mathrm{a}}$ & $16 \cdot 0 \pm 1 \cdot 00^{b}$ & $11 \cdot 5 \pm 0 \cdot 50^{\mathrm{c}}$ & $9 \cdot 0 \pm 1 \cdot 00^{\mathrm{d}}$ \\
\hline Streptococcus spp & $18 \cdot 5 \pm 0 \cdot 50^{\mathrm{a}}$ & $16 \cdot 0 \pm 0 \cdot 00^{b}$ & $12 \cdot 5 \pm 0 \cdot 50^{\mathrm{bc}}$ & $9 \cdot 0 \pm 0 \cdot 00^{\mathrm{c}}$ \\
\hline $\begin{array}{c}\text { Enterococcus faecalis } \\
\text { ATCC } 10231\end{array}$ & $17 \cdot 5 \pm 0 \cdot 50^{a}$ & $15 \cdot 5 \pm 0 \cdot 45^{b}$ & $13 \cdot 5 \pm 0 \cdot 50^{\mathrm{bc}}$ & $10 \cdot 5 \pm 0 \cdot 45^{c}$ \\
\hline Klebsiella pneumoniae & $19 \cdot 5 \pm 0 \cdot 50^{\mathrm{a}}$ & $16 \cdot 5 \pm 0 \cdot 50^{b}$ & $14 \cdot 5 \pm 0 \cdot 50^{\mathrm{bc}}$ & $11 \cdot 5 \pm 0 \cdot 50^{\mathrm{c}}$ \\
\hline $\begin{array}{c}\text { Escherichia coli ATCC } \\
35218\end{array}$ & $17 \cdot 5 \pm 0 \cdot 50^{\mathrm{a}}$ & $16 \cdot 0 \pm 0 \cdot 00^{\mathrm{a}}$ & $9 \cdot 0 \pm 0 \cdot 00^{\mathrm{c}}$ & $6 \cdot 0 \pm 0 \cdot 00^{c}$ \\
\hline $\begin{array}{c}\text { Escherichia coli ST2747 } \\
\text { (MDRs) }\end{array}$ & $14.5 \pm 0 \cdot 50^{\mathrm{a}}$ & $12 \cdot 0 \pm 0 \cdot 00^{\mathrm{ab}}$ & $8 \cdot 5 \pm 0 \cdot 00^{c}$ & $7 \cdot 0 \pm 0 \cdot 00^{\mathrm{c}}$ \\
\hline $\begin{array}{c}\text { Candida albicans ATCC } \\
334\end{array}$ & $21 \cdot 5 \pm 0 \cdot 50^{\mathrm{a}}$ & $16 \cdot 5 \pm 0 \cdot 50^{b}$ & $11 \cdot 5 \pm 0 \cdot 50^{\mathrm{c}}$ & $9 \cdot 5 \pm 0 \cdot 50^{c}$ \\
\hline
\end{tabular}

Mean values with different superscripts in the same column are significant different. Mean values were separated using Duncan Multiple Range Test (DMRT) (N=3)

Table 3: Effect of N-hexane Extract of Monodora myristica Seeds Extract on the Test Organisms Using Agar-well Diffusion Method

\begin{tabular}{|c|c|c|c|c|}
\hline \multirow[b]{2}{*}{ Organisms } & \multicolumn{4}{|c|}{ Concentrations / Zone of Inhibition (mm) } \\
\hline & $200 \mathrm{mg} / \mathrm{ml}$ & $150 \mathrm{mg} / \mathrm{ml}$ & $100 \mathrm{mg} / \mathrm{ml}$ & $50 \mathrm{mg} / \mathrm{ml}$ \\
\hline $\begin{array}{l}\text { Staphylococcus aureus ATCC } \\
6538\end{array}$ & $18 \cdot 0 \pm 0 \cdot 50^{\mathrm{a}}$ & $16 \cdot 5 \pm 1 \cdot 00^{\mathrm{a}}$ & $11 \cdot 5 \pm 0 \cdot 50^{\mathrm{b}}$ & $9 \cdot 0 \pm 1 \cdot 00^{\mathrm{c}}$ \\
\hline Streptococcus spp & $18 \cdot 5 \pm 0 \cdot 50^{\mathrm{a}}$ & $14 \cdot 5 \pm 0 \cdot 00^{\mathrm{b}}$ & $12 \cdot 5 \pm 0 \cdot 50^{\mathrm{bc}}$ & $9 \cdot 0 \pm 0 \cdot 00^{\mathrm{c}}$ \\
\hline $\begin{array}{l}\text { Enterococcus faecalis ATCC } \\
10231\end{array}$ & $16 \cdot 5 \pm 0 \cdot 50^{\text {a }}$ & $16 \cdot 5 \pm 0 \cdot 45^{b}$ & $13 \cdot 5 \pm 0 \cdot 50^{\mathrm{bc}}$ & $10 \cdot 5 \pm 0 \cdot 45^{\mathrm{c}}$ \\
\hline Klebsiella pneumoniae & $18 \cdot 5 \pm 0 \cdot 50^{\mathrm{a}}$ & $16 \cdot 5 \pm 0 \cdot 50^{\mathrm{b}}$ & $14 \cdot 5 \pm 0 \cdot 50^{\mathrm{bc}}$ & $10 \cdot 5 \pm 0 \cdot 50^{\mathrm{c}}$ \\
\hline Escherichia coli ATCC 35218 & $17 \cdot 0 \pm 0 \cdot 00^{\mathrm{a}}$ & $16 \cdot 5 \pm 0 \cdot 00^{\mathrm{a}}$ & $9 \cdot 0 \pm 0 \cdot 00^{\mathrm{c}}$ & $6 \cdot 0 \pm 0 \cdot 00^{\mathrm{c}}$ \\
\hline Escherichia coli ST2747 (MDRs) & $12.5 \pm 0 \cdot 50^{\mathrm{a}}$ & $11 \cdot 5 \pm 0 \cdot 05^{\mathrm{a}}$ & $8 \cdot 5 \pm 0 \cdot 00^{c}$ & $7 \cdot 0 \pm 0 \cdot 00^{\mathrm{c}}$ \\
\hline Candida albicans ATCC 334 & $20 \cdot 5 \pm 0 \cdot 50^{\mathrm{a}}$ & $14 \cdot 5 \pm 0 \cdot 50^{\mathrm{b}}$ & $11 \cdot 5 \pm 0 \cdot 50^{\mathrm{c}}$ & $7 \cdot 5 \pm 0 \cdot 50^{\mathrm{c}}$ \\
\hline
\end{tabular}


Table 4: Comparison of antimicrobial sensitivity of the extracts with antibiotics using agar-well and disc diffusion method

\section{Concentrations/ Zone of Inhibition (mm)}

\section{Organisms
Aqueous extract $200 \mathrm{mg} / \mathrm{ml}$

\section{N-hexane extract $200 \mathrm{mg} / \mathrm{ml}$}

A

\section{thanol extract \\ $00 \mathrm{mg} / \mathrm{ml}$}

D
D

$\begin{array}{lll}\text { A } & \text { D } & \text { A }\end{array}$

$13 \cdot 5 \pm 0 \cdot 50^{\mathrm{a}} \quad 13 \cdot 0 \pm 0 \cdot 00^{\mathrm{a}}$

$19 \cdot 5 \pm 0 \cdot 50^{\mathrm{a}}$

$18 \cdot 5 \pm 0 \cdot 50^{\mathrm{a}}$

$18 \cdot 0 \pm 0 \cdot 50^{\mathrm{a}}$

$18 \cdot 5 \pm 0 \cdot 50^{\mathrm{a}}$

$24 \cdot 5 \pm 0 \cdot 50^{\mathrm{a}}$

$27 \cdot 5 \pm 0 \cdot 50^{\mathrm{b}}$

ATCC 6538

Streptococcus

$12 \cdot 5 \pm 0 \cdot 50^{\text {a }}$

$12 \cdot 5 \pm 0 \cdot 50^{\text {a }}$

$18 \cdot 5 \pm 0 \cdot 50^{\mathrm{a}}$

$17 \cdot 5 \pm 0 \cdot 50^{\mathrm{a}}$

$18 \cdot 5 \pm 0 \cdot 50^{\text {a }}$

$16 \cdot 5 \pm 0 \cdot 50^{\text {a }}$

$26 \cdot 5 \pm \cdot 0.45^{\mathrm{ab}}$

$26 \cdot 0 \pm \cdot 00^{\text {a }}$

spp.

Enterococcus

$12 \cdot 5 \pm 0 \cdot 45^{\mathrm{a}} \quad 12 \cdot 5 \pm 0 \cdot 00^{\mathrm{a}}$

$16 \cdot 5 \pm 0 \cdot 50^{\mathrm{a}}$

$17 \cdot 0 \pm 0 \cdot 00^{\mathrm{a}}$

$16 \cdot 5 \pm 0 \cdot 50^{\mathrm{a}}$

$17 \cdot 0 \pm 0 \cdot 00^{\mathrm{a}}$

$24 \cdot 5 \pm 0 \cdot 15^{\mathrm{ab}}$

$28 \cdot 5 \pm 0 \cdot 50^{\mathrm{ab}}$

faecalis

ATCC 10231

Klebsiella

$13 \cdot 0 \pm 0 \cdot 50^{\mathrm{a}}$

$13 \cdot 5 \pm 0 \cdot 50^{\mathrm{a}}$

$19 \cdot 5 \pm 0 \cdot 50^{\mathrm{a}}$

$18 \cdot 0 \pm 0 \cdot 50^{\mathrm{a}}$

$18 \cdot 5 \pm 0 \cdot 50^{\text {a }}$

$18 \cdot 5 \pm 0 \cdot 50^{\text {a }}$

$24 \cdot 0 \pm 0 \cdot 00^{\mathrm{a}}$

$26 \cdot 0 \pm 1 \cdot 00^{\mathrm{ab}}$

pneumoniae

Escherichia

$9 \cdot 0 \pm 0 \cdot 00^{-1}$

$9 \cdot 5 \pm 0 \cdot 50^{\mathrm{a}}$

$17 \cdot 5 \pm 0 \cdot 50^{a}$

$17 \cdot 5 \pm 0 \cdot 50^{\mathrm{a}}$

$17 \cdot 0 \pm 0 \cdot 00^{a}$

$17 \cdot 5 \pm 0 \cdot 50^{\mathrm{a}}$

$20 \cdot 5 \pm 1 \cdot 00^{\mathrm{a}}$

$27 \cdot 0 \pm 0 \cdot 5^{\mathrm{b}}$

coli ATCC

35218

Escherichia

$6.0 \pm 0 \cdot 0$

$6 \cdot 0 \pm 0 \cdot 00^{\mathrm{a}}$

$12.5 \pm 0 \cdot 50$

$11 \cdot 0+0 \cdot 00^{\text {a }}$

$12.5 \pm 0 \cdot 50^{\mathrm{a}}$

$12 \cdot 0 \pm 0 \cdot 00$

$26 \cdot 0 \pm 0 \cdot 00^{\mathrm{a}}$

$25 \cdot 5 \pm 0 \cdot 5^{\mathrm{a}}$

coli ST2747

(MDRs)

Candida

$12 \cdot 5 \pm 0 \cdot 50^{\mathrm{a}} \quad 11 \cdot 0 \pm 0 \cdot 00^{\mathrm{a}} \quad 21 \cdot 5 \pm 0 \cdot 50^{\mathrm{a}}$

$19 \cdot 5 \pm 0 \cdot 00^{\mathrm{a}}$

$20 \cdot 5 \pm 0 \cdot 50^{\mathrm{a}}$

$19 \cdot 0 \pm 0 \cdot 00^{\mathrm{a}}$

Fluconazole

Nystatin $3 \mu g$

$25 \mathrm{mg} / \mathrm{ml}$

albicans

ATCC 334

Mean values with different superscripts in the same column are significant different. Mean values were separated using Duncan Multiple Range Test (DMRT) (N=3) Key: A- Agar diffusion, D- Disk diffusion, MDRs-

Multi-Drug Resistant strain 
Table 5: Minimum Inhibitory Concentration (MIC) and Minimum Cidal Concentration (MCC) of the Extracts

\begin{tabular}{|c|c|c|c|c|c|c|}
\hline \multirow[t]{3}{*}{ Organisms } & \multicolumn{6}{|c|}{ Concentrations (mg/ml) } \\
\hline & \multicolumn{2}{|c|}{ Aqueous Extract } & \multicolumn{2}{|c|}{ Ethanolic Extract } & \multicolumn{2}{|c|}{ N-Hexane Extract } \\
\hline & MIC & MCC & MIC & MCC & MIC & MCC \\
\hline $\begin{array}{l}\text { Staphylococcus } \\
\text { aureus ATCC } \\
6538\end{array}$ & 150 & 200 & 150 & 200 & 150 & 200 \\
\hline $\begin{array}{l}\text { Streptococcus } \\
\text { spp }\end{array}$ & 200 & - & 150 & 200 & 150 & 200 \\
\hline $\begin{array}{l}\text { Enterococcus } \\
\text { faecalis ATCC } \\
10231\end{array}$ & 200 & - & 150 & 200 & 150 & 200 \\
\hline $\begin{array}{l}\text { Klebsiella } \\
\text { pnuemoniae }\end{array}$ & 150 & 200 & 150 & 200 & 150 & 200 \\
\hline $\begin{array}{l}\text { Escherichia coli } \\
\text { ATCC } 35218\end{array}$ & - & - & 150 & 200 & 200 & - \\
\hline $\begin{array}{l}\text { Escherichia coli } \\
\text { ST2747 (MDRs) }\end{array}$ & - & - & 200 & - & 200 & - \\
\hline $\begin{array}{l}\text { Candida } \\
\text { albicans ATCC } \\
334\end{array}$ & 200 & - & 150 & 200 & 150 & 200 \\
\hline
\end{tabular}

Key: MDRs- Multi-Drug Resistant strain

Table 6: Qualitative Analyses of Monodora myristica Seeds Extracts

\begin{tabular}{llll}
\hline Phytochemical Components & \multicolumn{3}{c}{ Extracts } \\
& Aqueous & Ethanol & N-Hexane \\
\hline Alkaloids & ++ & +++ & +++ \\
Tannins & + & ++ & + \\
Phenolics & ++ & +++ & ++ \\
Glycosides & - & + & - \\
Terpenoids & - & - & - \\
Saponins & - & ++ & - \\
Flavonoids & - & - & - \\
Steroids & + & ++ & +++ \\
Phlobatannins & - & +++ & ++
\end{tabular}

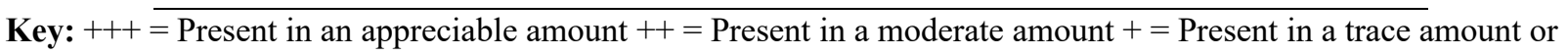
minute amount $-=$ Completely absent 


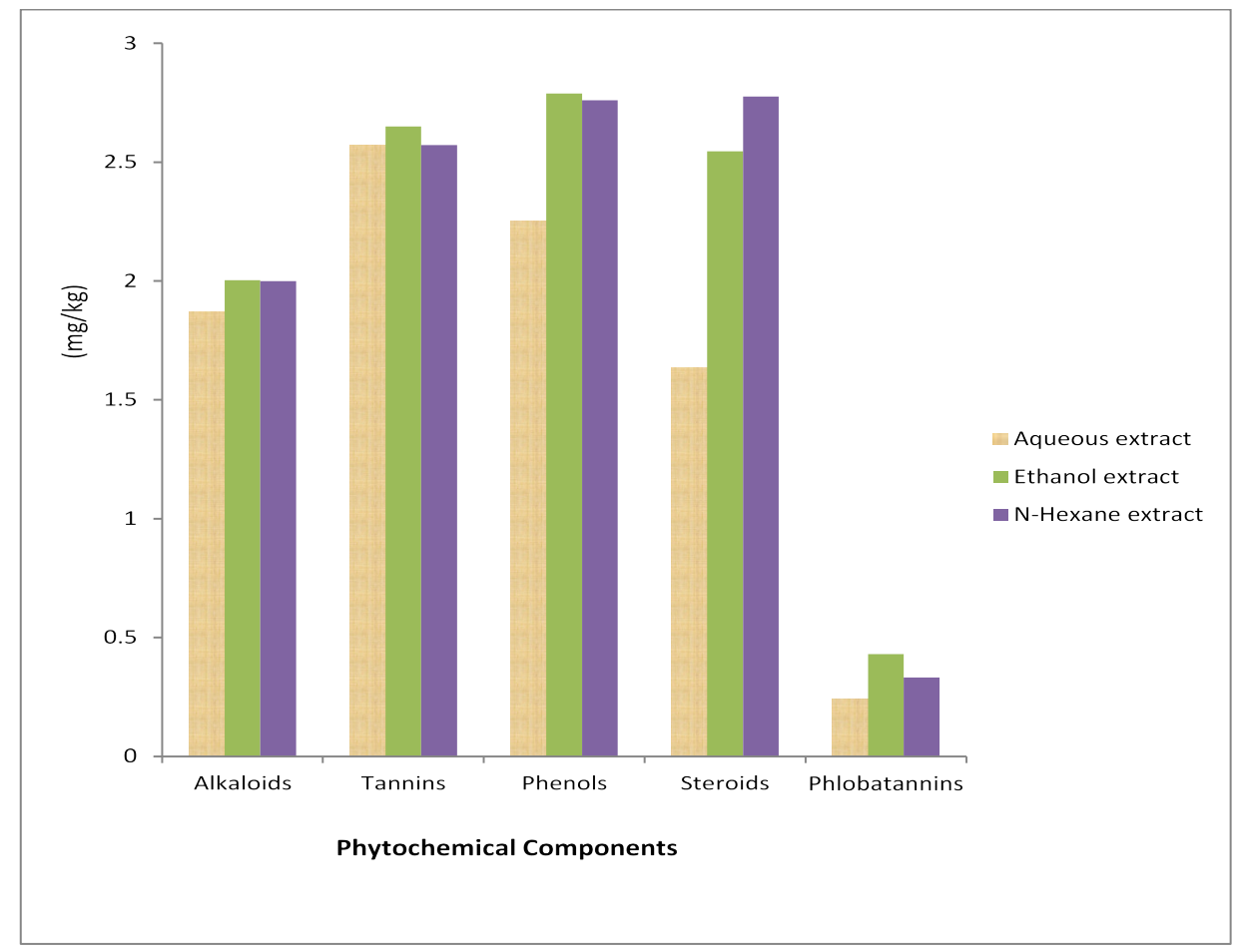

Figure 1: Quantitative Analyses of Monodora myristica Seeds Extracts

\section{Discussion}

The emergence of multiple drug resistant microorganisms is presently a global problem and a major cause of failure of the treatment of diseases (Awad and Aboud, 2015).

This study investigated the effects of aqueous, ethanolic, and n-hexane extract of Monodora myristica on some selected pathogens; Staphylococcus aureus, Streptococcus spp, Enterococcus faecalis, Klebsiella pnuemoniae, E. coli ST2747 (MDRs), E. coli ATCC S35218 and Candida albicans, found to be associated with various infections with significant risk of morbidity and mortality.

The efficacy of the aqueous extract of Monodora myristica seeds against test organisms was low which corroborated the work of Enabulele et al. (2014) this may be attributed to the absence and low phytochemical compounds as against the ethanolic and N-hexane extract. At the concentration of $200 \mathrm{mg} / \mathrm{ml}$ in (Table 2), it was observed that the aqueous extract of Monodora myristica seeds was mildly effective against Staphylococcus aureus and Klebsiella pnuemoniae statistically insignificant $(P<0.05)$ as compared with other test organisms which affirmed the work of Osuagwu (2013). Ethanolic extract was found to be most effective against all the test organisms at the $200 \mathrm{mg} / \mathrm{ml}$ as shown in Table 2. The n-hexane extract of Monodora myristica seeds was effective as ethanolic extract at the same concentrations, except against Escherichia coli ST2747 (MDRs), where it was mildly significant with $12.5 \mathrm{~mm}$.

Antimicrobial susceptibility testing showed that the organisms had higher susceptibility only on all the test organisms at $200 \mathrm{mg} / \mathrm{ml}$ and $150 \mathrm{mg} / \mathrm{ml}$ concentrations of the extracts. In antibiotics sensitivity testing, all bacteria showed high 
Page | 3682 extract was effective as standard antibiotics but the ethanolic extract was highly effective against Staphylococcus aureus, Streptococcus spp, Enterococcus faecalis, and Candida albicans except E. coli ST2747 (MDRs). E. coli ATCC S35218 was moderately susceptible to the ethanolic and n-hexane extracts.

The presence of alkaloids, phenols, saponins, steroids and tannins in Monodora myristica seeds has been reported by Osuagwu, (2013). Also, high concentrations of phenols and phlobatannins with trace amount of tannins in ethanolic extract of Monodora myristica seeds might have accounted for its antimicrobial and astringent properties (Ijeh, 2004; Enabulele et al., 2014).

The ethanolic extract has the most significant level of phytochemical components amongst the three solvents used for the extraction of Monodora myristica seeds, this depict that ethanol has the capacity to extract more phytochemical components than other solvents used in this study. The presence of these phytochemicals components in the seeds of Monodora myristica, confer it for its medicinal value (NNMDA, 2008). This study reveals that the more the phytochemical components the more its antimicrobial activity, which in line with (Ajayi et al., 2008).

\section{Conclusions}

This study reveals that Monodora myristica seeds extract at the highest concentration of $200 \mathrm{mg} / \mathrm{ml}$, showed varying degree of antimicrobial against test microorganisms associated with vagina infection. The phytochemical components of the seed extract found to be responsible for its antimicrobial activities. The n-hexane extracted pure oil with limited phytochemical components and it rendered moderate effectiveness a, while aqueous extract contains the lowest phytochemical components, and was the least effective against all pathogens, which is due oily nature of the seed; a non-polar solvent will be preferred for the extraction of Monodora myristica seeds, therefore, this study affirmed the efficacy of Monodora myristica seed extract against bacterial pathogens associated with vaginal infections.

\section{Conflict of Interest:}

The authors declare no conflicting interest in the publication No funding was obtained from any funding agency but the research was fully funded by the authors.

\section{References}

Adeyba, O.A., Adeoye, M.O., and Adesiji, Y.O. (2003). Bacteriological and parasitological vaginitis in pregnant women in iseyin, oyo state, Nigeria. ClinExpMicrobiol. 4:11-6.

Ajayi, I.A., Jonathan, S.G., Adewuyi, A., and Oderinde, R.A. (2008). Antimicrobial screening of the essential oil of some herbal plants from western Nigeria. World Applied Science3 (1), 79-81.

American Institute of Cancer Research (2000). New Survey: Older Americans abandon healthy diets, turn to supplements for lower risks, August 31 (http/www aier. Org/r $0331009 \mathrm{html}$ ) retrieved December 13, 2010.

Awad, A.I. and Aboud, E. A. (2015). Knowledge, attitude and practice towards antibiotic use among the public in Kuwait. PLOS ONE 10

Bamidele, F.A., Ogundipe, F.O., AdebayoOyetoro, A.O., Aromolaran, Odeyemi, O.A. and Omonigbeyin, E.A. (2013). In Vitro Antibacterial Activity and Preliminary Phytochemical Screening of Four Plants on Selected Clinical Pathogens. International 
Journal of Scientific and Research Publications 317-321.

Birt, D.A. (2006). Phytochemicals and cancer prevention: from epidemiology to

Page | 3683 mechanism of action. Journal of the American Dietetic Association 106: 20 - 24.

Bishnu, J.U., Sunil, L. and Anuja, S. (2009). Antibacterial propertities of different medicinal plants;Ocimum sanctum, Cinnamomum zeylanicum, Xanthoxylimarimatum and Origanum masorana. Kathmanda University Journal of Science, Engineering and Technology. 5:143-150.

Briskin, D.P. (2000). Medicinal plants and phytochemicals. Plant Physiology 124: 507 -514 .

Celtnet, R. (2011). "Calabash Nutmeg Information Page". ISBN 978-0-947643-010. Last visited April22, 2017.5:35pm.

Chalechale, A. and Karimi, I. (2010). The prevalence of Trichomonas vaginalis infection among patients that presented to hospitals in the Kermanshah district of Iran in 2006 and 2007. Turk J Med Sci. 40(6):971-5.

Duyff, R.L. (2000). Nutrition and Wellness, Glencore/ Mc Graw-Hill, United State of America, 576 pp.

Edeoga, H.O., Okwu, D.E. and Mbaebie, B.O. (2005). Phytochemical constituents of some Nigerian medicinal plants. African Journal of Biotechnology, (4):685 - 688 .

Enabulele, S.A., Oboh, F.O.J. and Uwadiae, E.O. (2014). Antimicrobial, nutritional and phytochemical properties of monodora myristica seeds. IOSR Journal of Pharmacy and Biological Sciences. 9(4):3, p01-06

FAO/WHO (2006). Probiotics in food. Health and nutritional properties and guidelines for evaluation. FAO Food and Nutritional paper No. 85 (ISBN 92-51055130). http//www. fao.com. Last visited march 2017.8:35am.

Felden, B., Vandenesch, F., and Bouloc, P. (2011). Staphylococcus aureus and its commitment to virulence. PLoSPathog. 7(3): e1002006.

Firn, R. (2010). Nature's Chemicals. Oxford University Press, Oxford.74-75.

Go, V.F., Quan, V.M., Celentano, D.D., Moulton, L.H. and Zenilman, J.M. (2006). Prevalence and risk factors for reproductive tract infections among women in rural vietnam. Southeast Asian. J Trop Med Public Health.; 37:185-9.PubMedGoogle Scholar

Gow, N.A.R. and Hube, B. (2012). Importance of the Candida albicans cell wall during commensalism and infection. Curr. Opin. Microbiol.15: 406-412.

Gupta, C., Amar, P., Ramesh, G., Uriya, C. and Kumari, A. (2008). Antimicrobial activity of some herbal oils against common food-borne pathogens. African Journal of Microbial Research. (2) 258-261

Hacer, H., Reyhan, B. and Sibel, Y. (2012).To determine of the prevalence of Bacterial Vaginosis, Candida sp, mixed infections (Bacterial Vaginosis + Candida sp), Trichomonas Vaginalis, Actinomycessp in Turkish women from Ankara, Turkey. Ginekol Pol.; 83:744-8.

Hayes, D.P. (2005). The protective role of fruits and vegetables against radiation - induced cancer. Nutrition Review 63: 303 - 322 ISBN-13: 9781555815394, pp: 11-25.

Kamba, A.S. and Hassan, L.G. (2010). Phytochemical screening and antimicrobial activities of Euphorbia balas amiferaleaves, stem and root against some pathogenic microorganisms. African Journal of 
Pharmaceutical Sciences and Pharmacy, (1), 57- 64 .

Kar, A. (2007). Pharmaocgnosy and Pharmacobiotechnology (Revised-Expanded Page | 3684 Second Edition). New Age International Limted Publishers New Delhi. (2):332-600.

Kuete, V. (2010). Potential of Cameroonian plants and derived products against microbial infections: A review. Planta Medica, 76: 1479-1491.

Lamichhane, P., Joshi, D.R., Subedi, Y.P., Thapa, R. and Acharya, G.P. (2014). Lamsal, A., Study on types of vaginitis and association between bacterial vaginosis and urinary tract infection in pregnant women. IJBAR 05(06):305-7.Google Scholar

Manach, C., Scalbert, A., Morand, C. Remesy, C and Limenez, L. (2004). Polyphenols: Food sources and bioavailability. American Journal of Clinical Nutrition 79: 727-747

Milner, J.A. (2002). Functional foods and health: a US perspective. British Journal of Nutrition 88: S151 - S158.

NCCLS (2006). Performance Standards for Antimicrobial Disc Susceptibility Test, $4^{\text {th }}$ Edition, Approved Standard M 2 - A 4, Villanova.

Nigeria Natural Medicine Development Agency (NNMA) (2008). Medicinal plants of Nigeria; South-East Nigeria. Vol.1. Lisida consulting Lagos Nigeria.204pp

Nwozo, S., Onyenibe E., Kasumu, T., Oyinloye, B. (2015).African Nutmeg (Monodora Myristica) lowers cholesterol And modulates lipid peroxidation in experimentally induced hypercholesterolemic male wistar rats. Int J Biomed Sci.; 11(2):86-92.
Okwu, D.E. (2001). Evaluation of the chemical composition of indigenous spices and flavouring agents. Global Journal of Pure and Applied Science 7 (3), 455-45.

Omobuwajo, T.O., Omobuwajo, O.R., and Sanni, L.A. (2003). Physical properties of calabash nutmeg (Monodoramyristica) seeds. J. Food Eng.; 57:375-381.

Omoyeni, O.A., and Aluko, B.T. (2010). Qualitative determination of chemical and nutritional composition of Cissus petiolata leaves. Electronic Journal of Environmental, Agricultural and Food Chemistry, 9 (2): 436-440.37.

Osuagwu, G. G. E. and Eme, C. B. (2013). The Phytochemical Composition and Antimicrobial Activity of Dialium Guineense, Vitex Doniana and DennettiaTripetala Leaves. Asian Journal of Natural and Applied Sciences, 2(3):169-181

Osuagwu, G.G.E. and Akomas, C.B. (2013). Antimicrobial activity of three Species of Nigerian Pterocarpus (Jacq.). International Journal of Medicinal and Aromatic Plants

Osuagwu, G. G. E. and Onwuegbuchulam, N.P. (2015). The Phytochemical Screening and Antimicrobial Activity of the Leaves of Monodora myristica, (Gaertn) Dunal, Acanthus montanus(Ness)T. Anders and Alstonia bonnie De Wild. International Journal of Pharmacy \& Pharmaceutical Research. 2:4

Performance standards for antimicrobial disk susceptibility tests. (2006). Approved standards. Clinical and Laboratory Standards Institute document M2-9. Clinical and Laboratory Inst. 940, West Valley Road, Suite 1400, Wayne, Pa., 19087-1898 USA.

Prospero, F.D. (2014). Focus on candida, trichomonas, bacteria and atrophic vaginitis. 
Available at http://womanhealthgate.com/ focus-candida-trichomonasbacteriaatrophic-vaginitis/

Ross, J., and Kasum, C. (2002). Dietary Page | 3685 flavonoids: bioavailability, metabolic effects and safety. American Review on Nutrition 22: 19-34. Secreted aspartyl proteinases invirulence and pathogenesis. Microbiol. Mol. Biol. Rev., 67: 400-428.

Sarker, S.D. and Nahar, L. (2007). Chemistry for Pharmacy Students General, Organic and Natural Product Chemistry. England: John Wiley and Sons.283-359.

Shariff, Z.U. (2001). Modern Herbal Therapy for Common Ailments. Nature Pharmacy Series. Spectrum Books Limited, Ibadan, Nigeria. In Association with Safari Books (Export) Limited, United Kingdom.9-84.

Siddhuraju, P. and Becker, K. (2003). Antioxidant properties of various solvent extracts of total phenolic constituents from three different agroclimatic origins of Drumstick tree (Moringa oleifera Lam.) leaves, J Agric Food Chem.51, 2144 -2155.

Spinillo, A., Bernuzzi, A.M., Cevini, C., Gulminetti, R., Luzi, S., and Santolo, A.D. (1997). The relationship of bacterial vaginosis, candida and trichomonas infection to symptomatic vaginitis in postmenopausal women attending a vaginitis clinic Maturitas. 27:253-60.

Treasure, I.O., Obaghwarhievwo, A.J. and Odigie, O. M. (2020). Ethnobotanical Survey of Medicinal Plants in Ughelli North Local Government Area of Delta State. Journal of Medicine: Study and Research. 3:014

UCSF (2014). McFarland Latex Standards from Hardy Diagnostics, measured at the UCSF
DeRisi Lab http//www.McFarland nephelometer standard.

Uwakwe, A.A., and Nwaoguikpe, R.N. (2008). In Vitro antisickling effects of Xylopiaaethiopica and Monodora myristica. Journal of Medicinal plant Research. 2(6):119-124.

Visioli, F., Borsani, L. and Galli, C. (2000). Diet and prevention of coronary heart disease: the potential role of phytochemicals. Cancer Research 47: 419 - 429.

Weiss, E. A. (2002) Spice crops. Oxon; CABI Publishing.p. 102.

World Health Organization (2001). Essential Drugs and Medicines Policy; WHO Geneva.

$\mathrm{Xu}$, B. J. and Chang, S.K.C. (2007). A comparative study on phenolic profiles and antioxidant activities of legumes as affected by extraction solvents. Journal of Food science72 (2): S159-66.

Xu, B.J. Yuan, S.H. and Chang, S.K.C. (2005). Comparative studies on the antioxidant activities of nine common legumes against copper-induced human low-density lipoprotein oxidation in vitro. Botanical Bulletin of Academia.

Zakariyah, R.F., Odebisi-Omokanye, M.B., Akolade, J.O., Ahmed, R.N., Jimoh, F.A. and Badmus, S.A. (2017). Screening of Prosopis Africana for antimicrobial activity against selected oral pathogens. Nigeria Journal of Pure \& Applied Sciences.30(2): p3049 